\title{
SOCIO-CULTURAL TRANSFORMATION OF UKRAINE IN THE CONTEXT OF EUROPEAN VALUES
}

\author{
Oleksandr Nosyriev', Tetiana Bukina²
}

\begin{abstract}
The article considers the issues of changing accents and cultural transformation in Ukraine, Great Britain and other European countries. In recent years, Ukraine has seen an active revival in the cultural sphere. From publishing to music, from film production to theater, from fashion to curatorial exhibitions - the Ukrainian cultural environment has become bold, diverse and large-scale. Euromaidan has given impetus to a powerful wave of cultural activism: from discussion platforms to spontaneous exhibitions, from urban regeneration projects to volunteer groups seeking to protect dilapidated national heritage sites. The impetus for it was the dynamism of the Ukrainian creative community. And further development became possible thanks to the support of new state cultural institutions. These institutes emerged after Euromaidan, such as the Ukrainian Cultural Foundation, the Ukrainian Book Institute, and the Ukrainian Institute. Institutions with a long history, such as the State Agency of Ukraine for Cinema, have strengthened their positions. The creation of these new institutions marked the departure from the post-Soviet system of cultural management. And the transition to a consistent and comprehensive cultural policy. The main thing is that the creation of a new system of culture in Ukraine has helped to bridge the gap between the state and cultural activists and the creative sector. One of the most important problems of the cultural sector in Ukraine for the last 25 years is funding. This problem is also relevant for the United Kingdom. But when it comes to finding resources for artists and cultural institutions, British policy has a respectable tradition and a number of successful answers. Support for the arts by both the state and business seems to be a matter of course for the British. At the same time, the idea of the self-worth of art is also supported by the idea of its social significance, as well as the perception of art as a primary source of creativity, innovative development, creative industry. The relationship between the European Union and the society of Ukraine is already yielding some results in the context of ensuring the democratic and European development of the state. For the successful implementation of European integration in Ukraine, it is necessary to apply such mechanisms that will ensure coordinated management of social processes of the state in the direction of European integration. The main mechanism is cultural policy, which should be aimed at regulating the regulatory framework. And the application of regulations in practice. This will allow culture to take a leading position on the path to national modernization. Legislation should be a mechanism for achieving goals, and the main thing should remain that the person should be at the center of cultural policy of the state. Given the experience of the United Kingdom, the formation of Ukraine's cultural policy should be based on the idea of the all-encompassing impact of culture on modern society. Accordingly, such a policy, being aimed at the cultural sector, effectively affects all spheres of public life. Consistent support for culture at the financial and fiscal, legislative and executive, national and local levels should, above all, be based on an awareness of the value of culture. Culture enriches people's lives, changes their worldview and inspires creativity. In the social dimension, its impact has the most significant impact on education, health and cohesion.
\end{abstract}

Key words: culture, cultural policy, state cultural policy.

JEL Classification: M14, D61, 131, 138, Z10

\footnotetext{
Corresponding author:

${ }^{1}$ National Technical University "Kharkiv Polytechnic Institute", Ukraine.

E-mail: nosyriev@ukr.net

ORCID: https://orcid.org/0000-0003-4089-3336

ResearcherID: AAN-2590-2020

${ }^{2}$ Pervomaisk affiliate National University of Shipbuilding Admiral Makarov, Ukraine.

E-mail: tanyshabukina@gmail.com

ORCID: https://orcid.org/0000-0003-3628-6859

ResearcherID: AAO-5442-2021
} 


\section{Introduction}

Following the revolutionary events of Euromaidan in 2013-14 and the subsequent Russian aggression against Ukraine, the country has seen a remarkable revival in the cultural sphere. From publishing to music, from film production to theater, from fashion to curatorial exhibitions - the Ukrainian cultural environment has become bolder, more diverse and larger. Euromaidan has given impetus to a powerful wave of cultural activism: from discussion platforms to spontaneous exhibitions, from urban regeneration projects to volunteer groups seeking to protect dilapidated national heritage sites. The impetus for this was the dynamism of the Ukrainian grassroots creative community, and further development has become possible due to the support of new state cultural institutions that emerged after Euromaidan, such as the Ukrainian Cultural Foundation, the Ukrainian Book Institute and the Ukrainian Institute (Kravchenko, 2015). Institutions with a longer history, such as Ukrainian State Film Agency, strengthened the position. The creation of these new institutions marked the transformation from the post-Soviet system of cultural management in the direction of a consistent and comprehensive cultural policy. The most important result is that the creation of new cultural ecosystem in Ukraine has helped bridge the gap between the state, its cultural activists and the creative sector.

Ukraine has made significant progress in shifting the emphasis in the controversy over culture previously it was seen as a waste of public funds, now it is increasingly seen as an important source of the national economy development, that is able to generate income and create jobs, promote innovation and social inclusion. Creative industries have become an important part of the discourse on cultural policy, but the public support of the sector remains weak.

\section{Socio-cultural trends determination in comparison with the developed countries}

Analyzing the modern conceptualization of cultural policy in Ukraine, O. Kravchenko (Kravchenko, 2015). states that it is based on the historical experience of the world's leading countries in the second half of the twentieth century on the instrumental use of the social potential of culture. Socio-cultural concepts "economy of culture", "cultural production", "creative industries", which are operated, in particular, by British scientists and government officials (Cultural policy and art education: process modeling, 2013), reflect the strategies of cultural policy as a way to meet social needs in accordance with the notions of quality of life in the paradigm of "human development". The researcher also notes that the basis of European cultural policy in recent decades are the ideas of decentralization and democratization of culture as ways to reconcile individual cultural rights and freedoms with the need of flexibly stimulation of the innovative dynamics of society.

O. Bezgin (Cultural policy and art education: process modeling, 2013) investigates the managerial experience of European countries in the arts and determines that the tradition of British cultural policy is based on the principles of national prestige, economic significance, "civilizational" mission and welfare state. The researcher covers the institutional and financial aspects of British policy in the field of culture and art. H. Tsymbalova's research, which focused on the foreign policy aspects of cultural policy, in particular, through the prism of the British Council, is also valuable for understanding of the British concept of cultural policy (Tsimbalova, 2015).

In the research of John Street it is not only shown the values in British cultural policy, but also highlighted the conflicts between the concepts of diversity, popularity and professional excellence in it. Analyzing this confrontation, the researcher examines how the specific political forces use competing evaluative judgments to manage the concepts of diversity and perfection, and whether the former is in fact populist and the latter is elitist in nature. This study helps to understand the ideological orientation of the current British policy in the field of culture (John Street, Dave Laing, Simone Schroff, 2015).

No doubt that one of the most important problems of the cultural sector in Ukraine for the last 25 years remains funding. This problem is also relevant for the Great Britain in the matter of finding resources for the activities of artists and cultural institutions.

British policy has a respectable tradition and a number of successful responses. The arts support by both the government and business seems to be a matter of course for the British. At the same time, the idea of the self-worth of art is also supported by the idea of its social significance, as well as the perception of art as the primary source of creativity, innovative development, creative industry. Thus, the culture supporting seems to be useful for business. The problem solution of the British art material support in the postwar period is understood as the need to attract funding not only of public sector but also private, to develop the activities of institutions aimed to search the funds, generating their own profit, and improving self-government systems. But the business support does not replace, it complements the government funding. At the same time, the government encourages mixed funding in art projects, which comes from various sources: the state, patrons, fundraising (including crowdfunding), as well as funds earned by the institutions themselves (2015 to 2020 government policy). Those cultural institutions that have revised their structure, management, business models and 
diversified sources of income have been able to adapt to changing economic circumstances. Similarly, the flexibility and adaptability are considered the key task of cultural organizations and the best response to changes in the financial environment, especially at the regional or local levels. At the same time, the government stimulates such development by making appropriate changes to the legislation, creating and maintaining funds with mixed sources of funding, tax benefits for cultural institutions and patrons (Mulcahy Kevin, 2006).

Strong public support and significant political interest in the cultural sector development have a corresponding social burden. David Cameron notes the interdependence of funding the culture and the arts at public expense (including the state budget) and open access to them for the public. Regardless the origin, everyone (children and youth above all) should enjoy the opportunities offered by culture. A clear embodiment of this policy is free entrance to museums, introduced in 2001. And now the government has maintained consistently free public access to the permanent collections and exhibitions of national museums and galleries. The growing demand to meet cultural needs, in particular, the rapid rise of the number of museum institutions visits over the next decade is associated with this event (Crossick, Kaszynska, 2016).

In the Culture White Paper, government programs and reports culture is seen as a powerful tool for revitalizing of the society and the economy at the national and local levels and the associated creative industry is considered to be one of the best investments the British can make. The Government recognizes the significant contribution of culture to the economic development, the labor market, education, improving the health and well-being of communities in villages, towns and cities, regions of the country. As examples of practical implementation of these ideas can be mentioned the creation of places of creativity, cultural quarters, which are aimed to be realized at the local level, opposed to large infrastructure projects (Mould Oli., Comunian Rober, 2015). Borrowed from the United States the cultural quarters establishment should bring together partners from the public, private, non-profit sectors. The aim of such association is to revitalize the local space with its buildings and streets, to improve the efficiency of local business and public safety, to involve to business and cultural industry different people who can generate jobs and profits, new products and services, and to attract and retain unrelated companies and skilled workers.

At the same time, the cultural policy implementation to revitalize the declining urban environments by creating cultural quarters with the creative industry is the subject of criticism in the recent scientific research, as such policy leads to marginalization of production, social gentrification, accompanied by rising of the real estate values, services and life in general in such quarters which results in the growing of inequality in urban space (The Culture White Paper, 2019).

However, the revival and restoration of quarters by means of culture does not imply, first of all, a direct economic effect, but the strengthening of ties between people and the growth of social capital.

\section{The Ukrainian cultural policy development in the conditions of European integration}

The strategically important document that defines the Ukrainian diplomacy vector was the Decree "On the Main Directions of Ukraine's Foreign Policy" approved by the Verkhovna Rada of Ukraine on July 2, 1993. It stated: "Given its geopolitical position, historical experience, cultural traditions, rich natural resources, strong economic, scientific, technical and intellectual potential, Ukraine can and have to become an influential world state that is capable to play the significant role in ensuring of the political and economic stability in Europe" (Botanova, 2016). The last important step towards the European Community was the signing of the Association Agreement between Ukraine and the European Union, on the one hand, the European Atomic Energy Community and their Member States, on the other hand, that was signed on March 21, 2014 (The Culture White Paper, 2019).

Most of the international agreements are focused on the economic and political issues. But it is important to note that convergence in the economic and political direction is not possible without cooperation and interaction in the cultural sphere. So, together with cooperation in the political, economic, and legal spheres, non-economic policy also becomes a priority, such as educational, linguistic, cultural, sports and other policies. The European cultural community has always promoted the belief that it is the culture (or rather the common cultural policy) that should be the basis of European integration processes. This discourse embodiment was the creation of an alliance in 1992, called the Culture Action Europe.

It should be considered that the cultural policy of European countries is open to the new forms and changes, but at the same time, it leaves behind each nation something traditional and unique to it. The enlargement of the European Union (EU) that is linked with the growth of the common market, migration, new trade links, education, globalization, increases contacts between cultures, religions, ethnic groups and languages. So, every citizen of the country has to understand one's belonging not only to one's own nation, but also to a community larger than the national - European. EU countries have formed their own common European values, symbols, ideas, which have created a common European society. 
The general principles of cultural policy in Europe are reflected in the UNESCO International Document "The Mexico City Declaration on Cultural Policies" (July 26 - August 6, 1982). The document states: "Any cultural policy should restore to development its profound, human significance, so the development plans and strategies have to be formed considering the historical, social and cultural context of each society. The assertion of cultural identity contributes to the liberation of peoples, and vice versa - any form of domination is a denial of identity or a threat to its existence" (EU Neighbours portal, 2020).

Thus, over the last decade, Ukrainians, especially the young generation, have become aware of themselves as Europeans. First of all, Ukraine needs to understand that "being a European" means accepting European values, which are often neglected in our post-Soviet society. For the post-Soviet population of Ukraine, where most people are brought up in a "socialist ideology", forced to experience "Soviet", although in fact it was "Russian" as "their own", it is difficult to perceive and identify oneself with the European world community, because European and American values were treated as "foreign".

So, the state policy of Ukraine has to be formed on the public awareness of new opportunities brought by European integration processes. In order to reach successful awareness more public information is needed on the following questions: "What is the EU?", "What is European integration?" etc. The majority of the population simply does not understand the differences between the European Union and the Council of Europe and other international organizations. According to the results of the survey, presented by the Institute of World Politics in the framework of the Program Enhance Non-Governmental Actors and Grassroots Engagement (ENGAGE) $37.5 \%$ of Ukrainians admitted that they need more information about the benefits of the Association Agreement, while $62.5 \%$ of Ukrainian citizens consider themselves sufficiently aware. At the same time, the greatest need for information was evidenced by residents of the Western and North-Central regions (42\% and 41\%, respectively), the smallest - residents of the Eastern region (26\%). The survey was conducted from May 17 to 24,2017 by telephone interview with calls to mobile phones. A total of 1,000 respondents aged 18 and older were interviewed (House of Europe, 'Our strategy, 2021).

The opportunity to be European for Ukrainians is an opportunity to have a high level of culture in society, which has recently been rightly correlated with a high standard of living, social consolidation, environmental security and many material benefits. European ideals and values are expressed in the recognition of civil and political rights, which guarantees everyone the opportunity to express their differences not only in spiritual, religious, political or philosophical views, but also in ways of life and self-expression. It is important for our state to establish cultural exchanges and dialogue, as well as change the system and approaches to governance in this area, which would be based on the principles of democracy, recognition of cultural rights and freedoms.

\section{Analysis of the low cultural activism research}

The Revolution of Dignity of 2013-2014 has become a massive canvas for artistic expression and an important stage for various public organizations that defended their right to "be a citizen, claim power and initiate change".

A number of public cultural initiatives have been emerged: experimental art and curatorial projects, crowdfunding-funded film festivals, an experimental theater dealing with the traumas of war through art, platforms for restoring post-industrial landscapes in the eastern Ukraine, groups to preserve the national heritage and different platforms to discuss identity. Like a number of other civil society initiatives in Ukraine at that time, this broad movement had similar features, including active citizenship, a horizontal structure, open dialogue and consensus building, and resourcefulness in funding (often using grant funding, usually provided by Western donors as well as crowdfunding within the country). In the result it was opened a new understanding of culture as a tool for development and social inclusion EU Neighbours portal (2020). The methods used in the sphere of culture are used for broader purposes, such as strengthening social cohesion, resilience, community empowerment, inclusion of vulnerable groups, urban regeneration and more.

While many of these initiatives were kept away from the government, including the Ministry of Culture and Information Policy of Ukraine, others sought to motivate the Ministry. A number of non-governmental organizations even organized the provocative selfseizure of the Ministry's premises in 2014. The action developed into a two-month open discussion in the ground floor of the Ministry between cultural activists, cultural managers and ministry officials, including the Minister on the cultural reform (House of Europe, 'Our strategy, 2021). In 2014, this Alliance began to develop a strategic document for the sustainable development of Ukrainian culture called "Culture 2025" and collaborated with the Ministry of Culture and Information Policy of Ukraine to develop its founding principles. Cooperation with the Ministry was made possible due to the appointment of experienced cultural leaders to senior positions in the Ministry, in particular Olesya Ostrovska-Lyuta was appointed Deputy Minister of Culture in 2014. Subsequently, 8 regional strategic sessions were held, covering 9 areas 
of culture and involving about 700 activists across the country (House of Europe, 'Our strategy, 2021).

Cultural activism and a network of NGOs have created parallel structures that have filled a gap created by an incompetent state. Their active involvement determined the model of cultural policy in Ukraine for the following years: collective and agreed decisions, not decisions made by civil servants in isolation from the community; cultural diversity, not monoculture; attention to different groups; a culture that is considered a factor in the development and improvement of society, not a "luxury item" (EU Neighbours portal, 2020).

Cultural policy reform in Ukraine has received strong support from a number of Western donors and partners. EU has been a major driver in this process, coordinating with national cultural institutions. The British Council and the German Goethe Institute played a leading role in this process. In 2007 EU launched a comprehensive program of cultural financial support, developing a "European Program of Cultural Development" (2015 to 2020 government policy). Lisbon Treaty of 2009 has provided the cultural cooperation between EU Member States and third countries.

In 2011 the program of cultural cooperation between EU and the Eastern Partnership countries was started with the aim of "cultural policy reform" and "cultural operators ensuring" in six Eastern Partnership countries: Ukraine, Belarus, Moldova, Georgia, Azerbaijan and Armenia. The program was developed for the period up to 2015, with a budget of 12 million Euros. It included the grant component - for the first time EU grants for culture became available in Ukraine, that aroused great interest (House of Europe, 'Our strategy, 2021). The Culture and Creativity Program (budget: 4,3 million Euro) was started in 2015 which became a platform for networking and discussion of cultural operators in the specified above countries and contributed to the development of capacity and understanding of the concept of "creative economy" (EU Neighbours portal, 2020).

Due to the coronavirus pandemic, House of Europe has launched a 0.8 million Euro emergency package for cultural organizations and professionals to find "new business models", "create digital projects" and purchase office equipment. Local experts estimate that the program could help 2,000 cultural activists.

Both the British Council and the Goethe Institute have played a significant role in implementing the EU's cultural policy in Ukraine. In addition, each of these institutions funds comprehensive programs in order to support civil society, education, culture and youth with the financial support of their national governments. After Euromaidan, these programs were scaled up.

The British Council's most effective program in this category is Active Citizens. It has promoted the civic activism development among young people in the regions of Ukraine and helped to create favorable conditions for the future cultural activity platforms.

The flagship program of the Goethe Institute in Ukraine, the Academy of Cultural Leaders, is aimed to fill the gap in the professional competencies of cultural operators in the regions of Ukraine. Working in partnership with the Ministry of Culture and Information Policy of Ukraine, the Goethe Institute found a balance in combining the Ministry's vision with the competence of German cultural experts that acted as facilitators, and in developing content adapted to the unreformed institutional environment of provincial Ukraine (House of Europe, 'Our strategy, 2021).

\section{Conclusions}

The relationship between the European Union and the society of Ukraine has been already yielding some results in the context of ensuring the democratic and European state development. For the successful implementation of European integration in Ukraine, it is necessary to apply such mechanisms that will ensure coordinated management of social processes of the state in the direction of European integration.

The main mechanism is the cultural policy, which should be aimed primarily at the legal framework regulating. On the practical application of regulations, it is important to ensure that culture takes a leading position on the path to national modernization. Legislation should be only the mechanism for the goals achieving, and the main is that a person should be at the center of cultural policy of the state.

Based on the experience of Great Britain, the formation of Ukraine's cultural policy should be based on the idea of the all-encompassing impact of culture on modern society. Accordingly, the policy, aimed at the cultural sector, effectively affects on all spheres of public life. Consistent support of culture at the financial, fiscal, legislative, executive, national and local levels should be based on an awareness of the value of culture. Culture enriches people's lives by changing their worldview and inspiring to the creativity. In the social dimension, its impact has the most significant impact on education, health and cohesion.

The economic dimension of cultural policy is also important due to the creative industry development, employment increase and the potential for revitalization of certain areas. However, inflated expectations about the direct economic effect of cultural policy, "monetization" of culture is a questionable conceptual approach, because its impact is manifested primarily in the growth of creativity and social capital of individuals and communities. Cultural policy should also be recognized as an important component of foreign policy aimed to increase the country's international prestige, attracting foreign investment and tourists. The public 
opinion formation, based on the specified above ideas, on the cultural sector importance is an urgent task for the state, along with the formation of appropriate public policy. Such ideological principles should become the base for the development of practical steps in the implementation of cultural policy in Ukraine.

The combination of three factors - civil society activism, political support of reforms and support of Western institutions of cultural relations - has created the unique window of opportunity to develop the qualitatively different state infrastructure in the field of culture in Ukraine. Three new institutions have appeared on the scene - the Ukrainian Cultural Foundation, the Ukrainian Institute and the Ukrainian Book Institute. And another, created before the Revolution of Dignity - the Ukrainian State Film Agency - has undergone significant restructuring. Several state museums and art venues, including the Oleksandr Dovzhenko National Center, the Art Arsenal, and the National Art Museum of Ukraine, have become centers for curatorial projects and discussion platforms.

The situation with the COVID-19 pandemic demonstrated the inconsistency of the policy of Ministry of Culture and Information Policy of Ukraine. The Ministry initially announced the reduction in the budgets of cultural institutions to $75 \%$, but agreed to a softer cut after protests of the heads of these institutions. As a result, the Ministry announced the allocation of an additional UAH 590 million
(16.6 million pounds sterling) for the "institutional support" of the creative sector in connection with the pandemic through a special Ministry's grant program. However, the conditions of these grants did not always correspond to the realities of the sector, and the demand for the program was low.

As decentralization reform has taken place in Ukraine in recent years, that means the transfer of powers from the central to the local level, funding from the state budget has stopped, but the newly formed communities have not been authorized to close basic cultural institutions and have to wait for approval from the Ministry. So many basic cultural institutions exist only "on paper".

Despite the resistance and inconsistency, the Ukrainian state has made significant progress in cultural policy reforming by creating the number of new cultural institutions based on the ideas of open access and stakeholder engagement. The Ministry of Culture and Information Policy of Ukraine has taken important steps to restructure itself, but these reforms have not been completed, so the danger of the rollback remains real. Ukrainian experience has shown that reforms have been made possible by a strong alliance of civil society activists and part of the creative and political elite that has supported change. External institutions on cultural relations have become catalysts for this process, investing in human capital and creating opportunities for new partnerships and competence development.

\section{References:}

Kravchenko, O. V. (2015). Key problems of modern cultural policy of Ukraine: culturological context. Culture of Ukraine, vol. 49, pp. 188-199.

Bezgin, O. I., Bernadska, A. E., Kocharyan, I. S., \& Uspenska, O. Y. (2013). Cultural policy and art education: process modeling. Kyiv: Institute of Cultural Studies, National Academy of Sciences of Ukraine, $176 \mathrm{p}$.

Tsimbalova, H. (2015). The emergence and development of cultural diplomacy and the British Council in the UK: stages of institutionalization. Scientific works of the historical faculty of Zaporizhia National University, vol. 44(2), pp. 68-72.

2010 to 2015 government policy: arts and culture. Available at: https://www.gov.uk/government/policies/ supporting-vibrant-and-sustainable-arts-and-culture

2015 to 2020 government policy: museums and galleries. Updated 1 June 2016. Available at: https://www.gov.uk/ government/uploads/system/uploads/attachment_data/file/529489/2016

John Street, Dave Laing, \& Simone Schroff (2015). Collective management organizations, creativity and cultural diversity. CREATe working paper. Glasgow: University of Glasgow, $30 \mathrm{p}$.

Crossick, J., \& Kaszynska, P. (2016). Understanding the value of arts \& culture. The AHRC Cultural Value Project. Swindon: Arts and Humanities Research Council, 204 p.

Mulcahy Kevin (2006). Cultural policy: Definitions and theoretical approaches. Journal of arts management law and society, vol. 35, issue 4, pp. 319-330.

Mould Oli, \& Comunian Rober (2015). Hung, drawn and cultural quartered: Rethinking cultural quarter development policy in the UK. European planning studies, vol. 23, issue 12, pp. 2356-2369.

Street John (2011). The popular, the diverse and the excellent: political values and UK cultural policy. International journal of cultural polis, vol. 17, issue 4, pp. 380-393.

The Culture White Paper (2019). London: Department for Culture, Media \& Sport.

Botanova, K. (2016). Culture and Art in Transforming Society. Culture and Education Academy: Encouragement and Guidance. Goethe Institut, p. 75.

EU Neighbours portal (2020). 'EU-Eastern Partnership Culture and Creativity Programme. Available at: https://www.euneighbours.eu/en/east/stay-informed/projects/eu-eastern-partnership-culture-and-creativityprogramme?fbdid=IwAR3jmhu4mSfYCfqWY962wxxyD1q3UcOSk4kUz3S7dXdERf0LitxMB9qYPzw

House of Europe, 'Our strategy (2021). Available at: https://houseofeurope.org.ua/en/our-strategy 